Section Editor

Mitchell S.V. Elkind,

MD, MS

Manish Kumar, MD

Radhika Dhamija, MD

Correspondence to

Dr. Kumar:

manishjipmer151280@gmail.com

\section{Teaching NeuroImages:}

Neurocutaneous melanosis

\title{
melanocytic nevus
}
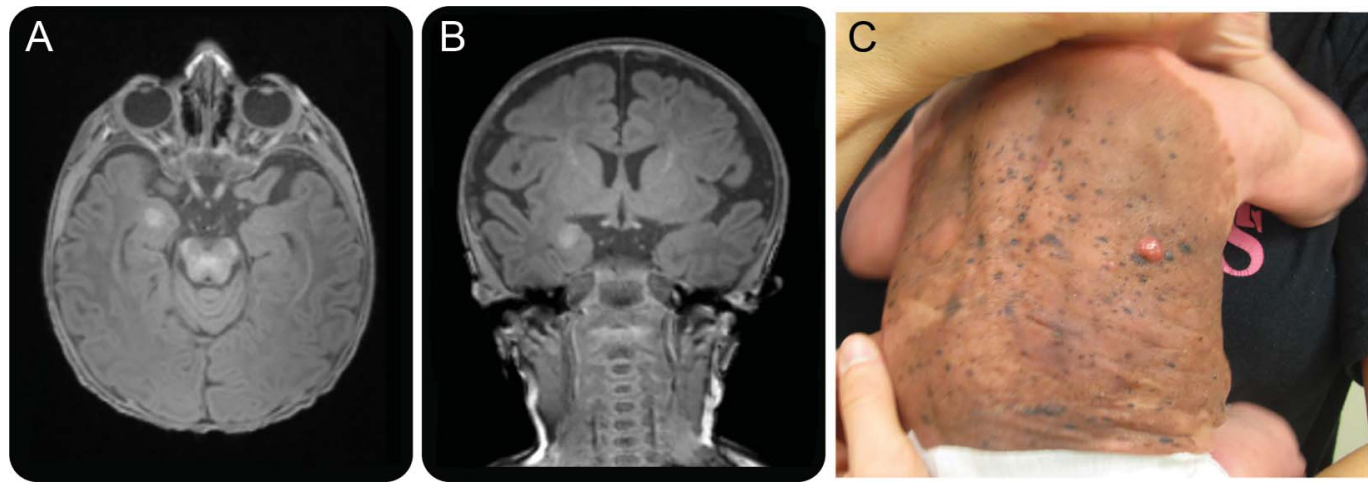

(A) Axial and (B) coronal views of multiplanar reconstructed images of the brain MRI demonstrate a single $8 \mathrm{~mm} \times 7 \mathrm{~mm} \times 6 \mathrm{~mm}$ lesion within the right amygdala with T1 shortening with no evidence of necrosis, hemorrhage, or edema. (C) The giant congenital melanocytic nevus.

A 3-month-old boy presented with a giant congenital melanocytic nevus involving his back. He was developing normally with no neurologic symptoms. Brain MRI demonstrated a T1-bright lesion in right amygdala without necrosis, hemorrhage, edema, or enhancement (figure). MRI spine was normal. The imaging findings in the clinical setting are consistent with a diagnosis of neurocutaneous melanosis.

First described by Von Rokitanski in 1861, neurocutaneous melanosis is a rare sporadic embryonic neuroectodermal dysplasia characterized by congenital melanocytic nevi and melanotic tumors of the leptomeninges or brain parenchyma. ${ }^{1}$ It most commonly results from an embryonic postzygotic somatic mutation in NRAS. ${ }^{2}$

\section{AUTHOR CONTRIBUTIONS}

Dr. Kumar: drafting the manuscript, chart review, analysis and interpretation of data. Dr. Dhamija: acquisition of data, study supervision, critical revision of the manuscript.

\section{STUDY FUNDING}

No targeted funding reported.

\section{DISCLOSURE}

The authors report no disclosures relevant to the manuscript. Go to Neurology.org for full disclosures.

\section{REFERENCES}

1. Kadonaga JN, Frieden IJ. Neurocutaneous melanosis: definition and review of the literature. J Am Acad Dermatol 1991;24:747-755.

2. Kusters-Vandevelde HV, Willemsen AE, Groenen PJ, et al. Experimental treatment of NRAS-mutated neurocutaneous melanocytosis with MEK162, a MEK-inhibitor. Acta Neuropathol Commun 2014;2:41. 


\title{
Neurology
}

\author{
Teaching NeuroImages: Neurocutaneous melanosis \\ Manish Kumar and Radhika Dhamija \\ Neurology 2015;84;e207 \\ DOI 10.1212/WNL.0000000000001689
}

\section{This information is current as of June 15, 2015}

\section{Updated Information \& Services}

\section{Supplementary Material}

\section{References}

Citations

Subspecialty Collections

\section{Permissions \& Licensing}

Reprints including high resolution figures, can be found at: http://n.neurology.org/content/84/24/e207.full

Supplementary material can be found at: http://n.neurology.org/content/suppl/2015/06/13/WNL.0000000000001 689.DC1

This article cites 2 articles, 0 of which you can access for free at: http://n.neurology.org/content/84/24/e207.full\#ref-list-1

This article has been cited by 1 HighWire-hosted articles: http://n.neurology.org/content/84/24/e207.full\#\#otherarticles

This article, along with others on similar topics, appears in the following collection(s):

\section{MRI}

http://n.neurology.org/cgi/collection/mri

Other neurocutaneous disorders

http://n.neurology.org/cgi/collection/other_neurocutaneous_disorders

Information about reproducing this article in parts (figures,tables) or in its entirety can be found online at:

http://www.neurology.org/about/about_the_journal\#permissions

Information about ordering reprints can be found online: http://n.neurology.org/subscribers/advertise

Neurology ${ }^{\circledR}$ is the official journal of the American Academy of Neurology. Published continuously since 1951, it is now a weekly with 48 issues per year. Copyright (C 2015 American Academy of Neurology. All rights reserved. Print ISSN: 0028-3878. Online ISSN: 1526-632X.

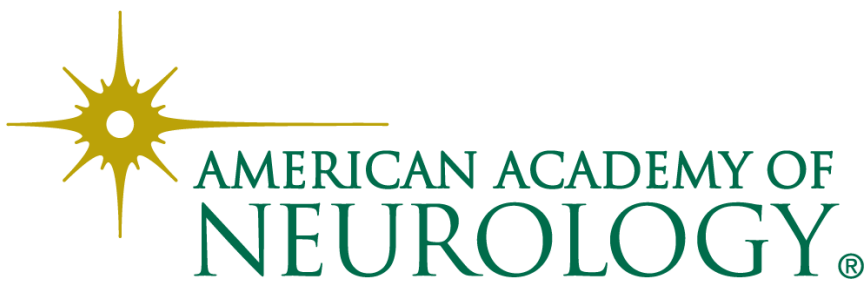

